\title{
SECURITIES REGULATION: DOCTRINES OF IN PARI DELICTO AND UNCLEAN HANDS HELD TO BAR 10b-5 RECOVERY BY TIPPEE A GAINST CORPORATE INSIDER
}

In Kuehnert v. Texstar Corp., ${ }^{1}$ the Court of Appeals for the Fifth Circuit applied the equitable doctrines of unclean hands and in pari delicto to deny recovery under section $10(\mathrm{~b})$ of the Securities and Exchange Act" and rule $10 \mathrm{~b}-5^{3}$ to a "tippee" injured as a result of reliance on false, non-public information received from a corporate insider. In January, 1965, Texstar Corporation began negotiations for a merger agreement with Coronet Petroleum Company under which Texstar, pursuant to a planned Type " $\mathrm{C}$ "" reorganization, would acquire the corporate assets of Coronet in exchange for Texstar stock. Rhame, then president of Texstar, informed a personal friend, Kuehnert, of the proposed, though unpublicized, acquisition, and of supposedly "secret" discoveries of oil on Coronet land which would result in dividends of $\$ 3$ per share plus a substantial increase in the value of Texstar stock. Kuehnert, relying on this confidential inside information, purchased large amounts of Texstar stock on margin in the open market." When Rhame's representations as to the oil discoveries and projeeted earnings proved to be false, Kuehnert was forced to sell his holdings at a loss. He sued Rhame and Texstar, alleging violations of section 10(b) of the Securities and Exchange Act ${ }^{\mathrm{i}}$ and rule 10b5. Rhame contended that plaintiff was barred from recovery by

'_ F.2d_-(5th Cir. 1969) (CCH Fed. SEC. L. ReP. If 92,406 (May 9, 1969)).

$=15$.U.S.C. \$ 78j(b) (1964).

$=17$ C.F.R. $\$ 240.10 \mathrm{~b}-5$ (1968).

' See B. Bittker \& J. kustice, federal income taxation of Corporations and SHAREHOLDERS $\$ 12.14$ (2d ed. 1966).

= Kuehnert purchased about 40,000 shares of Texstar prior to disclosure of the merger between Coronet and Texstar. In April of 1965 Texstar shareholders approved the merger. No mention at that time was made of the favorable oil discoveries or anticipated carnings. Nevertheless, upon reassurances of Rhame as to the validity of the information. Kuchnert continued to buy. Kuehnert sought recovery on these post-merger purchases.

615 U.S.C. $\$ 78 \mathrm{j}(\mathrm{b})(1964)$.

- 17 C.F.R. \$ 240.10b-5 reads: "It shall be unlawful for any person. directly or indirectly, by the use of any means or instrumentality of interstate commerce. or of the mails or of any facility of any national securities exchange, (a) To employ any device, scheme, or 
virtue of his own conduct in knowingly buying on the basis of undisclosed inside information." The district court granted the defendants' motions for summary judgment on the merits, holding that, even assuming Rhame gave Kuehnert information which Rhame knew to be fraudulent, Kuehnert was barred from recovery by his own misconduct as a tippee." ln a divided opinion the circuit court affirmed."

With passage of the Securities and Exchange Act in 1934, Congress continued the effort initiated in 1933 to protect the investor from fraud and deception on the Nation's securities markets." Directing its attention to the general trading of securities, Congress vested the Securities and Exchange Commission with broad rule-making powers to prevent the use of manipulative and deceptive devices in the purchase and sale of securities.'2 Pursuant to this mandate, rule $10 \mathrm{~b}-5$, the general antifraud provision, was promulgated." Intended as an extension of federal regulation of fraudulent practices by purchasers of securities, ${ }^{\text {, }}$ the ambit of rule 10b-5 has become a body of federal corporation law within itself, ${ }^{15}$ and the development of the rule in the area of insider trading has been pervasive. The preliminary step

artifice to defraud. (b) To make any untrue statement of a material fact or to omit to state a material lact necessary in order to make the statements made. in the light of the circumstances under which they were made. not misleading. or (c) To engage in an act. practice, or course of business which operates or would operate as a fraud or deceit upon any person, in connection with the purchase or sale of any security."

'See Ross v. Licht. 263 F. Supp. 395. 409-10 (S.D.N.Y. 1967).

286 F. Supp. 340 (S.D. Tex. 1968).

to__ F.2d _ (5th Cir. 1969).

"See 2 L. Loss. Seclrities Regulation 784-85 (2d ed. 1961) [hereinafter cited as Lossl.

12 Section 10(b) of the Securities and Exchange Act provides: "It shall be unlawful for any person, directly or indirectly, by the use of any means or instrumentality of interstate commerce or of the mails, or of any facility of any national securities exchange-.. . . (b) To use or employ. in connection with the purchase or sale of any security registered on a national securities exchange or any security not so registered, any manipulative or deceptive device or contrivance in contravention of such rules and regulations as the Commission may prescribe as necessary or appropriate in the public interest or for the protection of investors." 15 U.S.C. \$ 78j(b) (1964); see W. Painter, Federal Regulation of Insider Trading 19 (1968).

13 See generally. Note, Fiduciary Suits U'nder Rule 10b-5. 1968 DuKe L.J. 79I.

"See Cohen, "Truth in Securities" Revisited. 79 Harv. L. Rev. 1340, 1364-65 (1966).

"See. e.g. Schoenbaum v. Fïrstbrook, 405 F.2d 215 (2d Cir. 1968). See also Note, Breacl of Fiduciary Duty Involving Full Director Knowledge Held 10b-5 Violation. 1969 DUKE L.J. 383. 
came in 1947 with the development of an implied civil remedy for the aggrieved investor. ${ }^{15}$ However, the real evolution of the rule's application to insider trading began in 1961, when the Commission expressed its view that the disclosure obligations of rule $10 \mathrm{~b}-5$ extended to persons outside the "traditional" insider groups of directors, officers and shareholders." In disciplining a broker who had acted for certain discretionary accounts on the basis of confidential inside information, the Commission constructed a disclosure obligation which rested on the existence of a special relationship giving access to inside information intended only for corporate purposes and on the inherent unfairness of a party to a securities transaction acting with confidential information not available to other parties to the transaction. ${ }^{18}$ At least one court has held that tippees (persons given information by insiders in breach of trust) possess the same "special relationship" and consequently are subject to the same duty as insiders. ${ }^{19}$ However, this extension of "insider" to include the tippee had apparently never been approved by a circuit court. The Second Circuit has adopted a view of the 10b-5 "insider" seemingly broad enough to include the tippee, ${ }^{20}$ but has refused to consider tippee liability per se." Thus the issue of tippee culpability, though raised, was not settled.22

If the liability of a tippee to innocent third parties remained unsettled, the issue of liability between two wrongdoers, such as a tippee and an insider, remained untouched. As a general rule at common law, if parties were in pari delicto, a court would aid neither and leave the loss where it fell. ${ }^{23}$ Similarly, if an injured party seeking redress was guilty of misconduct on his own part, the doctrine of unclean hands would often be used to preclude relief.24

${ }^{16}$ Kardon v. National Gypsum Co., 73 F. Supp. 798 (E.D. Pa. 1947). See genterall! Note, Implying (ivil Remedies From Fuderal Regulatory Statutes, 77 HARv. L. REv. 285 (1963).

"In re Cady, Roberts \& Co., 40 S.E.C. 907 (1961).

ix Id. at 912 .

19 Ross v. Licht, 263 F. Supp. 395, 409-10 (S.D.N.Y. 1967).

to SEC v. Texas Gulf Sulphur, 401 F.2d 833, 847-48 (2d Cir. 1968); see W. PalNTter, supra note 12, at 223-24.

31 F.2d at 852-53.

22 For opinions of two writers on the liability of the tippee under rule $10 \mathrm{~b}-5$, see $\mathrm{W}$. PAINTER, supra note 12, at 142-43; 3 Loss 1450-51.

$\approx 3$ J. PONeroy. Equity JURISPRUDENCE $\$ 940$ (5th ed. 1941) (hereinafter cited as PoNeroy].

: 2 Poneroy $\$$ 397. Set genterally. Precision Instrument Mfg. Co. v. Automotive 
However, the doctrines were not without limitations, and courts refused to apply them where to do so would work a greater injustice on the public interest than nonapplication.". Similarly, where the defendant's misconduct far exceeded that of the plaintiff, courts frequently chose not to invoke the doctrines. ${ }^{26}$ The doctrines of unclean hands and in pari delicto have also been accepted as defenses under federal law, ${ }^{2 \pi}$ and can be raised by parties or courts themselves ${ }^{28}$ on the theory that they exist as protective devices for the integrity of the courts. ${ }^{29}$ An exception or limitation to their use, similar to the limitations applied at common law, has been the refusal to apply them where the plaintiff's action served a significant role in the enforcement of a federally-defined proscription created for the public benefit ${ }^{30}$ Thus, in an antitrust treble damage suit, denial of the defenses of in pari delicto and unclean hands has frequently been justified on grounds of the importance of the private treble damage action in advancement of the aims of antitrust legislation and of the greater public benefit to be achieved by allowing recovery without regard to the relative moral culpability of the parties. ${ }^{31}$ Such limitations are not absolute, however, and where the plaintiff has actively participated or initiated the scheme, or where his conduct might be termed that of a co-conspirator, the doctrines may still be available.:2

In pari delicto and unclean hands have been applied infrequently in the area of securities regulation ${ }^{33}$ In Gaudiosi $v$. Mellon; ${ }^{34}$ the defense of unclean hands was successfully asserted to deny declaratory relief in a proxy solicitation where the plaintiff had deliberately and maliciously violated S.E.C. proxy rules by

Maintenance Mach. Co., 324 U.S. 806 (1945): Z. Chafer. Some Problens of I:QUity 1 (1950). Traditionally rules of equity, time and the "single cause of action" have lead to the acceptance of in pari delicto and unclean hands in actions at law. See Union Pacific R.R. v. Chicago \& North Western Ry., 226 F. Supp. 400, 410 (N.D. III. 1964); 4 Poweroy $\$ 1368$.

ت See 3 PoneroY $\$ 941$.

zose id. at $\$ 942$.

: See, e.g. Precision Instruments Mrg. Co. v. Automotive Maintenance Mach. Co., 324 U.S. 806 (1945).

* See Ford v. Caspers. 42 F. Supp. 994, $997-98$ (N.D. 11l. 1941).

= See Gaudiosi v. Mellon. 269 F.2d 873, 882 (3d Cir.), cert. denied. 361 U.S. 902 (1959).

- See Perma-Life Mufflers, Inc. v. International Parts Corp., 392 U.S. 134. 139 (1968).

si id.

$=$ Id. at 140 .

a See 2 Loss 955-56.

=1 269 F.2d 873 (3d Cir.), cert. denied. 361 U.S. 902 (1959). 
intimidating shareholders. ${ }^{35}$ However, this action occurred prior to the Supreme Court's statement in J.I. Case Co. v. Borak that private actions concerning proxy rule violations, much like antitrust treble damage litigation, serves a necessary enforcement function:37 Nevertheless, since Borak at least one court has refused to recognize the importance of the public remedy"s and allowed the assertion of the unclean hands defense in proxy solicitation litigation..$^{39}$

In allowing the defendant in Texstar to present the plaintiff's misconduct as a defense, the circuit court in Texstar first decided that illegal conduct by the plaintiff could bar recovery in a private action under rule $10 \mathrm{~b}-5.0^{10}$ The court viewed the antitrust exception to the doctrine of in pari delictorl as being based on public policy grounds." However, the degree of public interest in allowing private securities law actions, where the question is merely one of accounting between joint conspirators, was deemed not comparable to the public interest involved in antitrust treble damage litigation with its far-reaching economic results. ${ }^{13}$ Furthermore, even in the antitrust context, in pari delicto might still apply where plaintiff and defendant were true co-conspirators." Since the same factors involved in the exception to in pari delicto in antitrust actions were not present in the instant securities action, the court decided in pari delicto was a viable doctrine in rule $10 \mathrm{~b}-5$ private litigation. The court reasoned that if Kuehnert actually had withheld material, inside information from his vendors, this active misconduct would have made him in pari delicto..$^{\sqrt{5}}$ However, since the information given Kuehnert was false and thus not material, the court had more difficulty with the question of whether Kuehnert's belief that he had material information was sufficient to create a disclosure obligation. Of particular importance to the court was the fact that

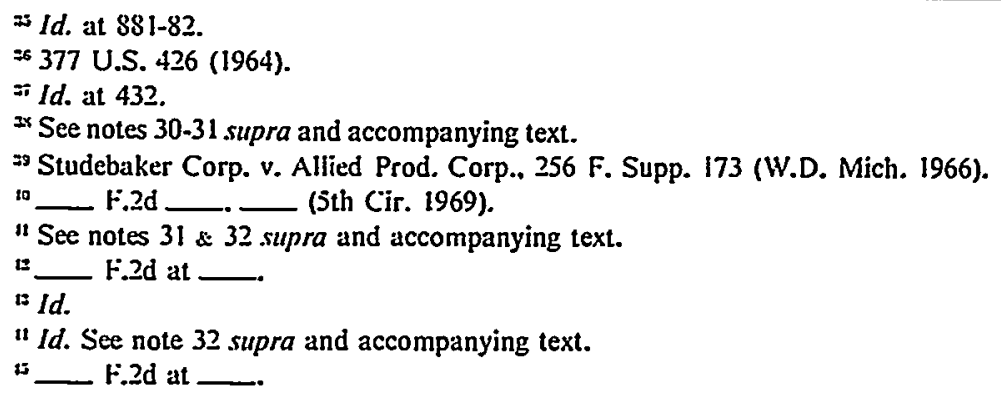


attempted fraud, potential fraud or unsuccessful fraud could bring Commission action..$^{45}$ Also, the court viewed both successful fraud and attempted fraud as within the section 10(b) language of "any manipulative or deceptive device." ' $^{-}$Since, in applying the equitable doctrine of unclean hands, courts were concerned only with the state of the plaintiff's mind, ${ }^{18}$ Kuehnert's fraudulent intent and status as a tippee was sufficient to bar recovery for unclean hands. ${ }^{49}$ Noting that the application of the doctrines was purely discretionary and that the question was one of policy, ${ }^{50}$ the majority of the Texstar court decided that denial of recovery in this instance, though it might encourage similar insider fraud, would be better than permitting tippee recovery, in effect giving him an "enforceable warranty that secret information [was] true."'si Since the growth of rule $10 \mathrm{~b}-5$ liability had not been stunted by the lack of tippee suits against the insider, and since substantial deterrent factors were already operating against the corporate insider, the court reasoned that the better choice was to leave the loss where it fell.j2

Of initial significance, though not surprising, was the Texstar court's holding, implicit in its discussion and use of in pari delicto and unclean hands, that rule 10b-5 disclosure obligations applied to the tippee trading with undisclosed information."3 The dissent in Texstar, though conceding tippee liability, would have had the court hold that the doctrines of in pari delicto and unclean hands are inapplicable to private actions under rule $10 \mathrm{~b}-5$. Indeed, the broad language of the Supreme Court in Perma-Life Mufflers, Inc. v. International Parts Corp., , $^{\text {s }}$ that these common law doctrines were inappropriate where "a private suit serves important public purposes, " 35 when read against the great development of rule 10b-5 that has resulted from private actions would apparently support this view. However, the argument for general inapplicability of the doctrine is questionable on several grounds. First, to deny courts

\footnotetext{
16 Id. at

"Securities and Exchange Act, 15 U.S.C. \$ 78j(b) (1964).

"See generally: 3 Loss 1451; W. PaINTER, supra note 12, at 143-44, 223-24.

19

so Id. at

il Id. at

52 Id. at ___ ; see note 23 supra and accompanying text.

- See notes 19-21 supra and accompanying text.

II 392 U.S. 134 (1968).

is $1 d$. at 138 .
} 
access to the doctrines of in pari delicto and unclean hands might deprive them of a valuable tool in protection of their integrity by allowing wrongdoers access to the courts to recover the fruits of their fraudulent act.5 Where the plaintiff has engaged in active misconduct, which is not only illegal but frustrates the disclosure of all material information as much as the conduct of the defendants, there seems no good reason why courts should not have discretion to deny him recovery $: 3$ Allowance of such discretion would give the court the opportunity to measure, in the light of public interest, "the substance of the right asserted by plaintiff against the transgression which, it is contended, serves to foreclose that right." ${ }^{58}$ Secondly, the proponents for general inapplicability of the doctrines have not fully established that Perma-Life completely obviated the use of in pari delicto and unclean hands in the antitrust context. There are implications that the doctrines may still be alive where plaintiff and defendant are true co-conspirators, ${ }^{30}$ suggesting that the Perma-Life holding goes to the discretion of the doctrines' use rather than to their total unavailability. Finally, the analogy of $10 \mathrm{~b}-5$ actions to the antitrust treble damage suit may be invalid, given the fact that private rule $10 \mathrm{~b}-5$ actions have developed without the necessity for actions by those who might be in pari delicto." In sharp contrast is the fear expressed in PermaLife that application of the doctrines might "threaten the effectiveness" or "seriously [undermine] the usefulness" of the private action as an enforcement tool of antitrust policy."

Thus, the real point to scrutinize in Texstar is not the court's determination that the equitable doctrines of in pari delicto and unclean hands were available in a securities law action, but rather the decision of the majority to allow the defenses to be asserted in the instant case so as to erase the possibility of the "defraudedtippee" suit. With the initial decision that the defenses were not barred generally as a matter of law, the question of application in

is $C$. Union Pacific R. R. v. Chicago and North Western Ry., 226 F. Supp. 400, 410 (N.D. III. 1964).

"See 2 Loss 955-56.

¿s Republic Molding Corp. v. B.W. Photo Utilities, 319 F.2d 347, 350 (9th Cir. 1963).

э9 Perma-Life Muffiers, Inc. v. International Parts Corp.. 392 U.S. 134, 140 (1968). Bull see id. at 148 (Marshall, J.e concurring in the result).

${ }^{60}$ Sece F.2d at

6) Perma-Life Mufners, Inc. v. International Parts Corp., 392 U.S. 134, 136. 139 (1968). 
Texstar became one of policy-a determination of whether allowing the defenses to deny recovery by the tippee would, in this case, better advance the securities law objective of investor protection. ${ }^{62}$ Preliminary to this determination was an identification by the court of the threat to investor protection presented in Texstar. As in many rule $10 b-5$ insider actions, the threat to the investor appeared to arise from the flow of confidential information from insider to tippee. Thus, the dissent in Texstar seemingly justifiably saw the majority's decision to place the burden of loss on the tippee rather than on the insider, the origin of dissemination, as "precisely the wrong way effectually to restrain tips from circulating." ${ }^{6: 3}$ Focusing on the tippee, the dissent reasoned, would simply have no deterrent effect on the source of the flow-the corporate insider. ${ }^{64}$ The fallacy of this criticism, however, lies in the assumption that a contrary decision in Texstar would have had a practical deterrent effect on the flow of confidential data. Whereas the possibility of the tippee action might deter the insider-tipster from giving knowingly false information to the tippee, it would have absolutely no preventive effect on the insider disseminating true information, potentially far more harmful to the outsider-shareholder. ${ }^{65}$ The more reasonable view is then that a contrary decision in Texstar would have had little, if any, net effect on the flow of inside information. On the other hand, as the majority likely realized, the setting in Texstar did present a very good opportunity for an attack on the use of inside information, that is, trading on the market with the benefit of confidential data. While present law theoretically prevented this use by the tippee, problems of detection and tracing made the sanction a questionable deterrent. Moreover, not only was present law less than effective against the use of confidential information, but, as the Texstar majority apparently saw, the "defrauded-tippee" suit represented a potential aggravation of the situation. If the tippee knew he could recoup trading losses should inside information prove false, he would thus likely never question

6 F.2d at

=Id. at _ـ (Godbold. J.. dissenting).

a Id. at _ـ_ (Godbold. J.. dissenting).

si Likewise, the "defrauded tippee" suit would not meet the case of dissemination of negligently false information since, in this situation of non-privity of the parties. the nontrading. misrepresenting party would likely be liable only for intentional misstatements. Sce Ruder, (ïil Liability. Lineler Rule I0b-5. 63 Nw. U.L. REv. 423, 444-45 (1968). 
the veracity of his tip and would be encouraged to use the tip to the detriment of other investors by trading on the open market where the chance of detection was slim. However, if the defrauded tippee were denied the availability of recovery, thus putting the risk of loss from the use of false information on him in every case, whether the tip was true or false, the tippee would be faced with the question or uncertainty of whether he should rely on inside information the veracity of which he is necessarily unsure. A reasonable conclusion is that faced with this dilemma, the tippee's use of inside informationhis trading activity - will likely be at a lower level than it would be were he assured of the truth of his tip. ${ }^{65}$ Thus, since the use of inside information by the tippee can be as much of a threat to the securities law policy of investor protection as the flow of confidential data from the corporate insider, the majority decision in Texstar to apply the doctrines of in pari delicto and unclean hands to bar recovery by a defrauded tippee seems the more effective method to protect that policy. 